prof. dr hab. Józef Marecki

UPJPII w Krakowie

\title{
Kłosy w polskiej heraldyce świeckiej
}

\begin{abstract}
Die Symbolik in der Heraldik ist eine spezifische Überlieferungsform. Unter den Symbolen auf Wappenschildern haben einen wesentlichen Platz die Ähren. Das Wappen besitzt - abhängig von der Wappenart - eine breite Bedeutungsvielfalt.
\end{abstract}

Key words: Symbolik, Heraldik, Ähren

Na tarczach herbów widnieją różnorodne godła przedstawiające zwierzęta i ptaki, broń i elementy uzbrojenia, rośliny i drzewa, przedmioty codziennego użytku, budowle, a także figury geometryczne. Wśród roślin, które pojawiają się na tarczach znaczącą grupę stanowią rośliny, w tym kłosy zbóż. W polskiej heraldyce widnieją kłosy pszenicy lub żyta. Nie występują kłosy innych zbóż. W większości jednak przypadków kłosy te nie są rozpoznawalne.

Kłosy zbóż oraz snopy są popularnymi godłami i elementami godeł. W heraldyce miejskiej wyobrażenia kłosów nawiązują do rolniczych terenów wokół miejscowości. Występują jako podstawowy element godła lub też jego część w połączeniu z innymi elementami. W kilku herbach miejskich widnieją snopy zbóż.

Celem wyjaśnienia dodać należy, że do świeckiej heraldyki zaliczamy herby rycerskie, szlacheckie, państwowe, miejskie i wiejskie oraz powiatów i gmin. Na wszystkich tych rodzajach herbów można znaleźć interesujące nas rośliny. Kłosy zbóż widnieją także na herbach wspólnot 
zakonnych, opactw i kapituł oraz na niektórych innych instytucji kościelnych. W rozważaniach ograniczymy się do herbów występujących na współczesnych ziemiach polskich.

W polskiej heraldyce szlacheckiej kłosy występują w herbach Kłosy (Ryc. 1) i Złotokłos. Pierwszy z wymienionych przedstawia w polu błękitnym trzy złote kłosy pszenne $\mathrm{z}$ listkami wyrastające z jednego korzenia o pięciu odnogach. Na obecnym etapie badań nie można podać genezy herbu. Herb ten znany jest na ziemiach polskich od XviI wieku'.

Znacznie rozbudowanym jest herb Złotokłos, który posiada tarczę trójdzielną w kształcie litery Y (rosocha). W polu górnym błękitnym podkowa srebrna, na której krzyż łaciński z dwoma podkowami srebrnymi zwróconymi do siebie barkami, w polu dolnym prawym złotym orzeł czarny w koronie złote, w polu trzecim dwudzielnym $\mathrm{w}$ pas, $\mathrm{w}$ jego polu górnym srebrnym trzy gwiazdy sześcioramienne złote, a w polu dolnym czerwonym trzy złote kłosy. Herb Złotokłos znany jest w Polsce od 1659 roku. Wówczas to kupiec i bankier Wilhelm Orsetti (1597-1659) - herbu Spiga d’oro - pochodzący z Italii, a który osiadł w Krakowie, został przyjęty indygenatem w poczet szlachty polskiej². Dodać należy, że przewiązany snop zboża widnieje w herbie Wazów.

Znacznie więcej wyobrażeń z kłosami zbóż występuje w heraldyce miejskiej i gminnej. Snop zboża widniał w herbie Wałcza (Ryc. 2), miasta, które po II wojnie światowej znalazło się w granicach Polski. Używany był do lat 6o. Przedstawiał w polu błękitnym trzy snopy kłosami w dól. Właściwie był to herb tzw. Starego Wałcza, który znany był od xviı wieku. Nowy Wałcz - w nawiązaniu do niemieckiej nazwy miasta - Deutsch Krone - posiadał herb z wyobrażeniem korony, który to herb został przyjęty w latach 6o. Współczesna wersja

1 J. Ostrowski, Księga herbowa rodów polskich, cz. 2, Warszawa 1901, S. 140 .

2 Por. J. Bieniarzówna, Orsetti Guglielmo (zm. 1659) [w:] Polski słownik biograficzny, t. 24, Wrocław-Warszawa-Kraków-Gdańsk 1979, s. 254. 
herbu, która została przyjęta przez Radę Miasta 17 września 2013 roku³, przedstawia w polu błękitnym złotą koronę z rubinami, pod którą sześcioramienna gwiazda srebrna i skrzyżowany miecz srebrny o złotej rękojeści ze liściem palmowym złotym. Wyobrażenie to nawiązuje do jednej z wersji herbów z połowy xvıI wieku4.

Snop zboża widnieje w herbie gminy Cegłów (pow. miński) przedstawiającym w polu czerwonym snop zboża, na tle którego misa srebrna z głową św. Jana Chrzciciela ${ }^{5}$. Warto wyjaśnić, że snop zboża nawiązuje do herbu Zygmunta III Wazy, który w 1621 roku nadał miejscowości prawa miejskie, a wyobrażenie głowy świętego na misie do warszawskiej kolegiaty pw. św. Jana Chrzciciela, która to kolegiata była właścicielem miejscowości od 1350 roku. W wyniku carskich restrykcji Cegłów utracił prawa miejskie w 1869 roku. Wówczas także zaniechano używania herbu ${ }^{6}$. Powrócono do niego w ostatniej dekadzie xx wieku, kiedy to Rada Gminy stosowną uchwałą przyjęła 26 czerwca 1991 roku dawny herb miasta za herb gminy.

Snop podtrzymywany przez anioła widnieje także w herbie gminy Zławieś Wielka (pow. toruński) ${ }^{8}$ oraz w herbie gminy Laszki (pow. jarosławski). W tym drugim przypadku przedstawia w polu tarczy zielonej dwa skrzyżowane snopy złote, na których siedzący jastrząb

3 Uchwała Nr vi/sxxxix/228/13 Rady Miasta Wałcz z dnia 17 września 2013 r. w sprawie ustanowienia herbu, sztandaru, flagi, banneru i pieczęci Miasta Wałcz (Dz. Urz. Woj. Zachodniopomorskiego z 2013 r., poz. 380o).

4 M. Gumowski, Herby miast polskich, Warszawa 1960, s. 334; T. Białecki, Herby Miast Pomorza Zachodniego, Szczecin 1991, s. 145.

5 Na temat atrybutów św. Jana Chrzciciela: J. Marecki, L. Rotter, Jak czytać wizerunki świętych. Leksykon atrybutów i symboli hagiograficznych, Kraków 2013, s. 380-381.

6 Przed 1628 rokiem w użyciu były wersje herbu $\mathrm{z}$ wyobrażeniem snopu zboża okolonego liśćmi wawrzynu, później dodano misę z głową św. Jana Chrzciciela.

7 Z. T. Gajowniczek, Na tropach tajemnic historii Cegłowa, Cegłów 1999; Tenże, Gmina wiejska i miejsko-wiejska w Polsce jako obszar odniesienia w edukacji regionalnej, Warszawa 2014, s. 49-50.

8 Uchwała Rady Gminy Zławieś Wielka Nr xx/231/2002 z 26 IV 2002 r. 
naturalny. Jak zaznaczono na oficjalnej stronie internetowej gminy najczęściej spotykanym w herbach symbolem rolnictwa sa kłosy. Dlatego też postanowiono je zastapić inna figura - dwoma snopkami, bowiem motyw ten praktycznie niemal nie pojawia się w heraldyce samorzadów. W herbie znalazł się też jastrząb naturalny, jako reprezentant tutejszej fauny (oprócz jastrzębi najczęściej można tu spotkać lisy i bobry). Ma on jednak nie tylko bezpośrednie odniesienie do miejscowej przyrody. Jastrząb uważany jest także m.in. za symbol wojowniczości, zwycięstwa i wzniosłości. Jeśli bowiem dokonamy retrospekcji wydarzeń - burzliwych dziejów tej ziemi, to wojowniczy jastrzą, strażnik strzegacy plonów, wydaje się najbardziej odpowiednim symbolem gminy ${ }^{9}$.

Kłosy zbóż, występujące samodzielnie, widnieją w kilku herbach. Tak jest w przypadku Jabłonowa Pomorskiego (pow. brodnicki) - miasta i gminy, której jest siedzibą - przedstawiającego w polu czerwonym trzy kłosy pszeniczne złote (Ryc. 3 ) $^{10}$. Miejscowość otrzymała prawa miejskie w 1962 roku. Wówczas to miasto przyjęło powyższy herb.

Kłosy występujące samodzielnie na tarczy herbowej widnieją także w herbie Górek Wielkich - miejscowości położonej na Śląsku Cieszyńskim. Przedstawia w polu błękitnym w dwóch rzędach jedenaście kłosów złotych, z których sześć dolnych posiada łodyżki z listkami. Projekt herbu przygotował w 1939 roku Marian Gumowski. Warto jednak przedstawić wcześniejsze wersje herbów, które zachowały się na tłokach pieczętnych. Najstarsze wyobrażenia godła pochodzą z pieczęci, którą uwiarygodniano wiejskie dokumenty. Jedna z zachowanych, datowana na 1788 rok, przedstawia snop zboża z piętnastoma kłosami. Kolejna pieczęć z wyobrażeniami szesnastu kłosów pochodzi z 1811 roku. Z kolei na odcisku pieczętnym z 1890 roku widnieje snop z jedenastoma kłosami. Inna natomiast jest pieczęć gminna z 1927 roku $\mathrm{z}$ wyobrażeniem oracza idącego za pługiem ciągnionym przez dwa

9 Herb i flaga gminy, http://laszki.pl/gmina/herb [21 XI 2015].

10 Por. A. Plewako, J. Wanag, Herbarz miast polskich, Warszawa 1994, s. 66. 
konie. Jak wspomniano wyżej w 1939 roku herb z przedstawieniem oracza zastąpiła wersja herbu z jedenastoma kłosami ${ }^{11}$.

W licznych herbach widnieją kłosy jako elementy godła. W herbie miejscowości i gminy Dobrzeń Wielki (pow. opolski), obok kłosa, widnieje kotwica. Herb przedstawia w polu zielonym błękitny pas w skos, na którym kłos pszenicy złoty w otoczeniu półkotwicy czarnej i półkrzyża złotego o rozstrojonych końcach. Kłos - jak powszechnie się przyjmuje - nawiązuje do miejscowych upraw rolnych, krzyż do religijnych tradycji Opolszczyzny i herbu Opola ${ }^{12}$, natomiast kotwica nawiązuje do przemysłu stoczniowego, który rozwinął się wzdłuż Odry przepływającej przez terytorium gminy. Rzekę symbolizuje błękitny pas na tarczy herbowej.

Kłos jest także jednym z elementów godła w herbie gminy Łodygowice (pow. żywiecki). Herb przedstawia w tarczy dzielonej w krzyż w polu prawym górnym zamek, w polu drugim zielonym skrzyżowane klucze złote, w polu trzecim zielonym kłos złoty, w polu czwartym złotym żaglówkę (Ryc. 4). Elementy poszczególnych pól nawiązują do przeszłości, charakteru i specyfiki miejscowości wchodzących w skład gminy. W Łodygowicach znajduje się zamek Warszyckich, dawnych właścicieli miejscowości. Skrzyżowane klucze - atrybut św. Piotra - nawiązują do Pietrzykowic, których założycielem miał być według tradycji sołtys Piotr. Z kolei kłos symbolizuje Bierną - wieś słynącą z rolnictwa, a żaglówka do Zarzecza, która to miejscowość jest położona nad brzegiem Jeziora Żywieckiego ${ }^{13}$. Projekt herbu wykonały Renata Talik i Maria Dobija ${ }^{14}$.

11 M. Gumowski, Herby i pieczęcie miejscowości województwa śląskiego z 438 rycinami, Katowice 1939, s. 170; A. Znamierowski, Pieczęcie i herby Śląska Cieszyńskiego, Górki Wielkie-Cieszyn 2011, s. 44-45.

12 W polu błękitnym pół orła górnośląskiego złotego złączonego z połową złotego krzyża o rozstrojonych końcach.

13 Por. Herb gminy Łodygowice, http://www.lodygowice.pl/nasza-gmina/ herb.html [12 XII 2015].

14 Projekt herbu zatwierdziła Rada Gminy Łodygowice (uchwała nr x/140/o3) w dniu $18 \times 2003$ r. 
W herbie Koluszek, miejscowości, która prawa miejskie uzyskała w 1949 roku $^{15}$, kłos zboża jest jednym z trzech elementów godła. Współczesny herb przedstawia w polu czerwonym uskrzydlone koło kolejowe czarne w skos, na którym gęsie pióro pisarskie srebrne i kłos złoty w skos lewy (Ryc. 5). Jedna z wcześniejszych wersji przedstawiała $\mathrm{w}$ polu błękitnym uskrzydlone koło kolejowe czerwone w skos, z którego wychodzą pióro pisarskie srebrne i kłos złoty ${ }^{16}$. Koło kolejowe nawiązuje roli, jaką odegrała kolej w rozwoju miejscowości, które od Xıx wieku było znaczącym węzłem kolejowym i ośrodkiem transportu dla okolicznego przemysłu włókienniczego. Gęsie pióro jest symbolem pisarskiej twórczości Władysława Reymonta (1867-1925)17 mieszkającego i tworzącego w pobliżu Koluszek. Kłos pszenicy odnosi się do rolniczego charakteru okolic miejscowości. Twórcą powyższego herbu, wyłonionego w konkursie ogłoszonym 6 grudnia 1946 roku, jest Bronimir Cywiński. Przyjęcie herbu uchwaliła Miejska Rada Narodowa Koluszek 22 maja 1948 roku, a potwierdziła decyzja Prezydium Powiatowej Rady Narodowej w Brzezinach podjęta 24 lipca 1948 roku $^{18}$.

Nieco zbliżonym do herbu Koluszek jest herb Korsz, który został przyjęty przez Radę Miasta 18 września 1991 roku. Miejscowość uzyskała prawa miejskie w 1962 roku. Herb przedstawia w polu zielonym trzy kłosy złote w słup z łodygami i źdźbłami czarnymi, poniżej których koło kolejowe czerwone z skrzydłami złotymi ${ }^{19}$. Nawiązując do wyobrażeń kłosów we współczesnej wersji należy wspomnieć o wcześniejszym herbie z okresu międzywojennego. Wersja ta przedstawiała w polu tarczy podzielonej krzyżem czarnym w polu pierwszym i trzecim romby czerwono-złote, w polu drugim srebrnym koło złote, a w czwartym

15 Rozporządzenie Ministra Administracji Publicznej z dnia 1 IV 1949 r. w sprawie utworzenia miasta Koluszki. Dz. U. RP 1949, nr 24, poz. 165.

16 A. Plewako, J. Wanag, Herbarz..., s. 87.

17 J. Rurawski, Władysław Reymont, Warszawa 1988.

18 Por. M. Adamczewski, Pieczęcie urzędowe władz lokalnych z obszaru Polski centralnej, cz. 3, Łódź 2010, s. 299-300.

19 A. Plewako, J. Wanag, Herbarz..., s. 90. 
trzy kłosy zboża złote. Współczesny herb został przyjęty w początkach lat 90. $\mathrm{xx}$ wieku ${ }^{20}$. Kolejowe koło zarówno w dawnej ${ }^{21}$ jak i w obecnej wersji nawiązuje do kolei, która w rozwoju miejscowości odegrała znaczącą rolę, natomiast kłosy do rolniczego charakteru miejscowości.

Do rolniczego charakteru miejscowości nawiązują także elementy herbu Kazimierzy Wielkiej, która prawa miejskie otrzymało w 1959 roku, a w 1999 została ustanowione siedzibą powiatu ${ }^{22}$. Herb miasta jest także elementem herbu powiatu kazimierzowskiego ${ }^{23}$. Herb miasta przedstawia w polu czerwonym godło herbu Pomian ${ }^{24}$, poniżej którego dwa kłosy pszenicy (Ryc. 6). Powyższa wersja herbu została przyjęta przez Radę Narodową w 1979 roku $^{25}$. Znana jest inna wersja herbu przedstawiająca poniżej godła Pomian wyobrażenie czerwonego buraka okolonego kłosami pszenicy. Wyjaśnić należy, iż herb Pomian jest znakiem rodu Łubieńskich, którzy od końca Xviı wieku byli właścicielami miejscowości. Znacznie przyczynili się do podniesienia poziomu gospodarczego regionu i wprowadzenia nowych form upraw rolnych i przetwórstwa ziemiopłodów.

20 Wygląd herbu określa Załącznik nr 2 do uchwały Nr xıII/81/2007 Rady Miejskiej w Korszach z 28 Ix 2007 r.

21 W okresie międzywojennym używano herbu zatwierdzonego w 1927 roku, który przedstawiał na tarczy dzielonej w krzyż krzyżem czarnym w polu pierwszym i czwartym romby złoto-czerwone, w polu drugim srebrnym uskrzydlone koło kolejowe złote, w polu trzecim srebrnym trzy kłosy złote. Herb Korsz, http://www.korsze.com/Historia\%2oKorsz/herb.htm [10 XII 2015].

22 S. M. Przybyszewski, Kazimierza Wielka, Kielce 2002, s. 5onn.

23 Na tarczy dwudzielnej w słup w polu prawym czerwonym żubrza głowa czarna przebita mieczem pomiędzy rogami w skos, w polu lewym błękitnym krzyż patriarchalny złoty. Uchwała Rady Powiatu w Kazimierzy Wielkiej (nr XXII/171/2009) z 6 XI 2009 r.

24 W polu złotym żubrza głowa czarna przebita mieczem pomiędzy rogami w skos. Por. K. Niesiecki, Herbarz polski, t. 4, Lipsk 1841, s. 371; A. Znamierowski, Herbarz rodowy, Warszawa 2004, s. 110; A. Znamierowski, P. Dudziński, Wielka księga heraldyki, Warszawa 2008, s. 104-108.

25 A. Plewako, J. Wanag, Herbarz..., s. 79. 
Nieco zbliżonym do powyższego jest herb miejscowości i gminy Rudniki (pow. oleski) ${ }^{26}$. Przedstawia w polu zielonym głowę byka srebrną $\mathrm{z}$ takim kolcem w nozdrzach $\mathrm{z}$ dwoma kłosami pszenicy złotymi w miejscu rogów, między którymi godło herbu Lis (Ryc. 6) ${ }^{27}$.

Dwa kłosy widnieją w herbie gminy Dzierżoniów, który Rada Gminy przyjęła 27 sierpnia 2009 roku. Herb przedstawia w polu błękitnym figurę Matki Bożej z Dzieciątkiem i berłem złotą na takiej półkuli pomiędzy dwoma kłosami złotymi. Do 2009 roku w użyciu był herb przedstawiający w polu błękitnym figurę Matki Bożej z Dzieciątkiem w szatach złotych na tle trzech pagórków zielonych u podstawy tarczy, na których lemiesz czarny. Figura nawiązuje do łaskami słynącego wizerunku Matki Bożej czczonej w świątyni parafialnej w Kiełczynie, a kłosy do rolniczego charakteru terenu gminy.

Do rolniczego charakteru miejscowości wchodzących w skład gminy nawiązuje herb Izbicka (pow. strzelecki), który używa także gmina Izbicko. Na tarczy widnieją kłosy, wizerunek dzika oraz karpia. Wyobrażenie dzika pochodzi z herbu rodu Strachwitz, który od 1811 roku do zakończenia II wojny światowej był właścicielem rozległych dóbr ziemskich na Dolnym Śląsku - m. in. Izbicka i okolicy ${ }^{28}$. Kłosy nawiązują do rozległych upraw rolnych i zajęć miejscowej ludności, a karpie - do okolicznych hodowlanych stawów rybnych.

Dwa kłosy widnieją w herbie gminy Hoczewo (pow. wejcherowski), który przedstawia w polu błękitnym świecącą promieniami złotymi latarnię morską czerwoną o podstawie biało-czarnej i wieży złotej na złotym wzgórzu pomiędzy dwoma kłosami złotymi. Herb nawiązuje do nadmorskiego położenia gminy i latarni morskiej wzniesionej

26 Herb zatwierdziła Rada Gminy w Rudnikach (Uchwała nr xxxi/176/97) w dniu 29 XII 1997 r.

$27 \mathrm{~W}$ polu czerwonym rogacina srebrna dwa razy przekrzyżowana. A. Kulikowski, Wielki herbarz rodów polskich, Warszawa 2005, s. 238-239.

28 Izbicko - historia, http://portal-strzelce.pl/strony/izbicko-historia/ [27 XI 2015]. 
na wierzchołku wydmy w początkach xx wieku w Osetniku (miejscowość wchodząca w skład gminy Hoczewo).

Dwa kłosy widnieją także w herbie gminy Stary Lubotyń (pow. ostrowski). Herb przedstawia w polu zielonym dwa krzyże procesyjne złote, z których prawy zakończony słońcem a lewy księżycem rogami w prawo, pomiędzy dwoma kłosami złotymi z prawej i takąż ostrogą w słup z lewej (Ryc. 7). Poszczególne elementy nawiązują do dawnej struktury własnościowej poszczególnych miejscowości wchodzących w skład gminy: kanoników regularnych z klasztoru czerwieńskiego (krzyże procesyjne) i szlachty (ostrogi) oraz wiosek włościańskich (kłosy) ${ }^{29}$.

Herb Janikowa (pow. inowrocławski) przedstawia w polu czerwonym Orła Białego, poniżej którego ostrosłup solny i dwa odwrócone od siebie kłosy złote w pas pomiędzy kominami brązowymi. W dolnej części tarczy widnieje niekiedy nazwa miejscowości. Pierwotnie herb posiadał inne barwy: tarcza była złota, Orzeł Biały umieszczony był w tarczy czerwonej, kominy czerwone, a kłosy złote w czarnym obrysie. Wersja ta została przyjęta w 1975 roku $^{30}$. Należy wyjaśnić, że godło państwowe umieszczone w herbie - według jego twórców - miało przypominać, że miejscowość uzyskała prawa miejskie w 1962 roku (w okresie PRL) $)^{31}$, ostrosłup solny i kominy nawiązywały do kombinatu sodowego (obecnie Janikowskich Zakładów Sodowych „Janikosoda” sA) powstałego w latach 1953-1957 roku, a kłosy zboża do rolniczego charakteru okolicznych miejscowości.

Zbliżonym nieco w kompozycji do poprzedniego jest herb Libiąża, miejscowości, która prawa miejskie uzyskała w 1969 roku $^{32}$. Przedstawia w tarczy dwudzielnej w słup w polu prawym czerwonym połuorła piastowskiego, w prawym złotym zabudowania kopalni węgla, poniżej

29 Herb gminy Stary Lubotyń, http://www.encyklopedia.biolog.pl/index. php?haslo=Herb_gminy_Stary_Luboty\%C5\%84 [27 XI 2015].

30 A. Plewako, J. Wanag, Herbarz..., s. 66.

31 E. Krause, Monografia historyczna Miasta i Gminy Janikowo - od pradziejów ludzkości do końca Xx wieku, Janikowo 2002, s. 7.

32 A. Plewako, J. Wanag, Herbarz..., s. 105. 
których wstęga zielona z poziomo ułożonymi odwróconymi od siebie kłosami złotymi. W czole tarczy w polu czarnym napis srebrny LıBıĄż (Ryc. 8) ${ }^{33}$. Herb zaprojektowany przez plastyka Lecha Chwastowskiego, został przyjęty w 1968 roku przez Miejską Radę Narodową, nawiązuje do rolniczego charakteru okolicy i libiąskiej kopalni węgla „Janina” założonej w 1907 roku $^{34}$.

Kłos zboża, jako jeden z elementów godła, widnieje w herbie miejscowości i gminy Czerwionka-Leszczyny (pow. rybnicki), która prawa miejskie uzyskała w 1962 roku. Opracował go Sylwester Musiolik, a zatwierdziła Rada Miejska w 1977 roku $^{35}$. Herb przedstawia w tarczy dwudzielnej w słup w polu prawym połuorła piastowskiego na tle muru ceglanego, w polu lewym zielono-czarnym skrzyżowane młotki górnicze czarne ze złotymi trzonkami na tle kłosa zboża złotego w słup. Kompozycja nawiązuje do piastowskich początków osady oraz rolniczo-przemysłowego jej charakteru.

Identyczne elementy herbu - orzeł, kłosy i górnicze młotki - widnieją w herbie miasta i gminy Brzeszcze (pow. oświęcimski). Herb wyobraża w polu błękitnym orła górnośląskiego złotego, na piersi którego tarcza heraldyczna zielono-czarna dzielona w pas z trzema kłosami zboża złotymi i skrzyżowanymi młotkami górniczymi złotymi. Motywy kłosów i młotków górniczych umieszczone na zielono-czarnej tarczy (kolorystyka rolnictwa i przemysłu górniczego) przypominają o głównych zajęciach mieszkańców Brzeszcz i okolicznych miejscowości. Tarcza oraz śląski orzeł ${ }^{36}$ nawiązuje do lokalizacji miejscowości w granicach Śląska. Herb został zaprojektowany z okazji nadania miejscowości praw miejskich 7 lipca 1962 roku $^{37}$.

33 W niektórych wersjach herbu widnieje w górnej części tarczy majuskułowy napis LIBIĄż.

34 M. Leś-Runicka, Historia kopalni węgla kamiennego Janina w Libiążu, Libiąż 2008.

35 Por. A. Plewako, J. Wanag, Herbarz..., s. 103.

36 W błękitnej tarczy orzeł złoty bez korony, zwrócony w prawo.

37 A. Plewako, J. Wanag, Herbarz..., s. 19. 
Godło państwowe (Orzeł Biały), kominy i kłosy są elementami godła Myszkowa. Herb przedstawia w polu błękitnym cztery kominy czarne, z których środkowych unosi się dym, na ich tle godło państwowe pomiędzy dwoma kłosami złotymi w słup, w podstawie tarczy wstęga błękitna pomiędzy czarną i brązową ${ }^{38}$. Kominy i kłosy zboża oraz wstęga czarna i brązowa nawiązują do przemysłowo-rolniczego charakteru okolic Myszkowa ${ }^{39}$, a błękitna wstęga do rzeki Warty przepływającej przez miasto. Herb zatwierdziła w 1969 roku Miejska Rada Narodowa ${ }^{40}$.

Kłosy, obok budowli przemysłowych i innych elementów godła, widnieją w herbie Gogolina (pow. krapkowicki) przyjętego w 1987 roku. W polu czerwonym piec wapienny biały, na tle którego pomnik tańczącej pary pomiędzy dwoma kłosami w słup (Ryc. 9) ${ }^{41}$. Elementy powyższe nawiązują do istotnych elementów historii i tradycji Gogolina. Piec symbolizuje przemysł wapienny, z którego znane jest miasto, tańcząca para nawiązuje do pomnika Karolinki i Karlika - bohaterów śląskiej pieśni ludowej. Pomnik wykonał rzeźbiarz Tadeusz Wencel. Uroczyste odsłonięcie pomnika miało miejsce 28 maja 1967 roku, w dniu, w którym Gogolin uzyskał prawa miejskie. Złote pszeniczne kłosy symbolizują nie tylko rolniczy charakter Opolszczyzny, ale i dobrobyt oraz majętność i mieszkańców Gogolina ${ }^{42}$. Przyjęte w opisywanym herbie kolory nawiązują do barw narodowych.

W kilku przypadkach kłosy zbóż widnieją w herbach w połączeniu z innymi narzędziami. W herbie Dziergowic (pow. kędzierzyńsko-kozielski) widnieją w polu błękitnym ${ }^{43}$ trzy kłosy złote $\mathrm{z}$ jednej ło-

38 W wersjach wcześniejszych herbu poniżej kominów widniała podstawa czerwona tarczy z błękitną wstęgą.

39 Ponad 50 \% tereny Myszkowa zajmują użytki rolne.

40 A. Plewako, J. Wanag, Herbarz..., s. 134.

41 Uchwała Rady Narodowej Miasta i Gminy w Gogolinie z dnia 24 maja 1987 roku w sprawie ustanowienia herbu dla miasta Gogolina.

42 Por. A. Plewako, J. Wanag, Herbarz..., s. 53.

43 Znany jest także herb $\mathrm{z}$ tarczą dwudzielną w słup z polem czerwonym i zielonym. 
dygi na tle takichż skrzyżowanych dwu radeł (szpadli, łopat), nad którymi powrósło złote. Powyższe elementy widnieją na zachowanych pieczęciach gminnych z końca XIX wieku. Przypominają o rolniczym charakterze miejscowości. Należy dodać, że skrzyżowane radła występują w herbie Piotra (Petra) Dluhomila (zm. 1595), który nabył Dziergowice $\mathrm{w} 1575 \mathrm{roku}^{44}$.

Z kolei w herbie gminy Barciany (pow. kętrzyński) występuje w polu zielonym topór srebrny o złotym toporzysku między dwoma kłosami pszenicy (Ryc. 10). Herb nawiązuje do znaku pieczętnego miejscowości, która wcześniej nosiła nazwę Barten ${ }^{45}$, co wywodzi się od niemieckiej nazwy topora lub też od pruskiego bart - co oznacza płynąć. Kłosy widoczne w herbie przypominają o rolniczych tradycjach gminy. Wyjaśnić należy, że miejscowość Barciany używa herbu, na którym w czerwonym polu tarczy widnieje topór srebrny o złotym toporzysku.

W herbie miejscowości i gminy Subkowy (pow. tczewski) widnieje $\mathrm{w}$ tarczy dzielonej w skos w polu prawym srebrnym gryf czerwony z źdźbłem o dwóch kłosach, w polu zielonym pół koła złotego. Kłosy i koło nawiązują do rolniczego charakteru okolicy. Gryf nawiązuje do księcia pomorskiego Mściwoja II (zm. 1294) ${ }^{46}$ - jednego z pierwszych właścicieli miejscowości.

Inne narzędzie, koło czerpakowe koparki, widnieje w herbie gminy Kleszczów (pow. bełchatowski), miejscowości położonej w pobliżu Bełchatowa słynącego $\mathrm{z}$ kopalni węgla brunatnego. Herb wspomnianej gminy przedstawia w trójdzielnej tarczy w rosochę w polu górnym złotym czerpak koparki czarny, w polu prawym zielonym dwa krzyżowane

\footnotetext{
44 Herb Dziergowic, http://dziergowice.pl/herb-dziergowic,15 [12 XI 2015].

45 Na temat historii Barcian: K. Górski, M. Arszyński, Barciany. Dzieje zamku i ziemi do połowy xv wieku, Olsztyn 1967; J. Sikorski, Historia wsi Barciany, http://www.jerzysikorski.pl/historia-wsi-barciany [18 XI 2015].

46 K. Jasiński, Jeszcze o Zwinisławie żonie Mszczuja I, „Zapiski Towarzystwa Naukowego w Toruniu", 16:1950, s. 85 (przyp. 8); G. Labuda, Fragmenty dziejów Słowiańszczyzny Zachodniej, t. 3, Poznań 1975, s. 314-316.
} 
kłosy złote, a w polu lewym zielonym jodłę złotą⒎ Wyjaśnić należy, że czerpak symbolizuje położoną na terenie gminy odkrywkową Kopalnię Węgla Brunatnego „Bełchatów”, której zasoby zasilają pobliską elektrownię, kłosy - urodzajną ziemię i uprawy zbóż na terenie gminy oraz przemysł rolniczy, a jodła nawiązuje do obszarów rezerwatów przyrody, w których dominują jodły ${ }^{48}$.

Obok kłosów, fragment koła zębatego widniał w dawniejszej wersji herbu Łochowa (pow. węgrowski) ${ }^{49}$, który przedstawiał w polu czerwonym monogram nazwy miejscowości okolonego kłosem i fragmentem koła zębatego w barwach złotych. Wersja ta, przyjęta przez miejscową Miejską Radę Narodową w 1977 roku $^{50}$. Obecnie w użyciu jest herb przedstawiający w polu zielonym łeb łosia złoty ${ }^{51}$.

Koło zębate, obok kłosów, widoczne było w dawnym herbie Pieszyc (pow. dzierżoniowski), miejscowości, która prawa miejskie otrzymała w 1962 roku. Herb przedstawiał w polu czerwonym piastowskiego Orła Białego, na piersi którego w pasie górnym dwie tarcze błękitne z kłosem złotym w słup na jednej i czółenkiem tkackim złotym na drugie, w pasie dolnym tacza złota $z$ kołem zębatym czarnym ${ }^{52}$. Kłos przypominał o rolniczym charakterze okolicy, a czółenko o tradycji manufaktur tkackich i fabryk włókienniczych działających na terenie Pieszyc od xviII wieku. Podobnie - koło zębate - nawiązywało do produkowanych w Pieszycach i w okolicznych miejscowościach maszynach i urządzeniach tkackich.

47 Herb zaprojektowało Centrum Heraldyki Polskiej w Warszawie; został zatwierdzony uchwałą Rady Gminy Kleszczów (nr XLVIII/49/97) w dniu 14 XI $1997 \mathrm{r}$.

48 Symbole gminy Kleszczów, http://www.kleszczow.com/symbole.php [10 XI 2015].

49 S. Sęczyk, Dzieje Łochowa i okolic, http://kapliczkiwpolsce.blogspot. com/2012/11/dzieje-ochowa-i-okolic-wg-stanisawa.html [12 XII 2015].

50 A. Plewako, J. Wanag, Herbarz..., s. 117.

51 Por. Krupa T., Nasz herb, „Gazeta Łochowska” nr 103 (135): 2006.

52 A. Plewako, J. Wanag, Herbarz..., s. 162. 
Herb miejscowości i gminy Lipce Reymontowskie53 (pow. skierniewicki) przedstawia $\mathrm{w}$ tarczy trójdzielnej w polu górnym czerwonym otwartą księgę srebrną, w polu prawym zielonym krzyż złoty, poniżej którego dwa kłosy złote, w lewym złotym drzewo ukorzenione zielone (Ryc. 11). Poszczególne elementy godła nawiązują do publikacji Chłopi pióra Władysława Reymonta, w której opisał wydarzenia jakie rzekomo wydarzył się w Lipcach ${ }^{54}$. Krzyż przypomina o założeniu miejscowości przez arcybiskupa gnieźnieńskiego Janisława w 1338 roku i pożności mieszkańców wsi, o czym świadczy m. in. duża liczba przydrożnych kapliczek i krzyży, a kłosy o rolniczym charakterze Lipiec Reymontowskich. Warto dodać, że wzniesiony w II połowie XIX wieku kościół parafialny został konsekrowany pw. Znalezienia Krzyża Świętego. Ostatni z elementów - lipa - nawiązuje do nazwy miejscowości, a liczba korzeni do liczby dziewięciu sołectw wchodzących w skład gminy 55 .

Połączenie krzyża z kłosami, co widoczne było w wyżej przedstawionym herbie miejscowości i gminy Lipce Reymontowskie, pojawia się w kilku innych herbach. Herb gminy Morzeszczyn (pow. tczewski) przedstawia $\mathrm{w}$ tarczy zielonej $\mathrm{w}$ pas $\mathrm{w}$ polu górnym zielonym dwa złote kłosy, pomiędzy krzyż srebrny, w polu dolnym złotym dąb zielony. Kłosy nawiązują do rolniczego charakteru powiatu tczewskiego, na terenie którego położona jest gmina. Krzyż symbolizuje przywiązanie do chrześcijaństwa oraz do działalności cystersów na terenie ziemi morzeszczyńskiej, którzy w pobliskim Pelplinie założyli znane z działalności religijnej, agrarnej, oświatowej i kulturalnej opactwo.

53 Przymiotnik „Reymontowskie” dodano do nazwy miejscowości od 1 I 1984 r.

54 Powieść Chłopi powstała w latach 1901-1908; w 1924 r. autor otrzymał nagrodę Nobla w dziedzinie literatury.

55 Herb przyjęła Gmina w 1998 r. Por. Kalendarium Gminy Lipce Reymontowskie, http://www.lipcereymontowskie.pl/index.php?p=historia_kalendarium [1 XII 2015]. 
Z kolei dąb nawiązuje do krajobrazu i gospodarki leśnej - teren gminy pokrywają lasy i dębiny ${ }^{56}$.

Krzyż i kłosy widnieją w herbie gminy Udanin (pow. średzki), który to herb przedstawia $\mathrm{w}$ tarczy dzielonej w krzyż w srebrnym polu górnym prawym orła świdnicko-jaworskiego ${ }^{57}$, w czerwonym polu drugim trzy kłosy złote, w polu trzecim szachowanie biało-czerwone, a w czwartym złotym budynek kościoła czerwonego zwieńczonego krzyżem (Ryc. 12). Kłosy - podobnie jak w innych herbach - nawiązują do rolniczego charakteru gminy, dobrobytu mieszkańców, herb Bolka I Srogiego (ur. ok. 1252/56-1301) ${ }^{58}$. przypomina o władcy ziem w XIII wieku, pole szachowane do barw księstwa brzesko-legnickiego ${ }^{59}$, na terenie którego leżał Udanin, a kościół o najstarszej na terenie gminy świątyni, którą wzniesiono w początkach XIII wieku w Udaninie pw. Najśw. Maryi Panny (obecnie pw. św. Urszuli) ${ }^{60}$.

Krzyż, obok kłosów, widnieje w herbie miejscowości i gminy Olszanka (pow. łosicki). Herb przedstawia w polu czerwonym trzy kłosy złote, nad którymi z prawej krzyż maltański złoty i patriarszy złoty z lewej. Według opisu zamieszczonego na oficjalnej stronie Urzędu Gminnego każdy z elementów ma swoja symbolikę: trzy kłosy; symbolizuja zarówno rolniczy charakter gminy jak i hojność Matki-Ziemi, z płodów której hojnie korzystaja mieszkańcy, krzyż militarny; nawiązuje

56 Symbolika herbu Gminy Morzeszczyn, http://nowa.morzeszczyn.pl/herb-gminy/symbolika-herbu-gminy-morzeszczyn.html [12 XII 2015].

57 Wyobrażenie orła, zwanego świdnicko-jaworskim (połuorła czarnego fragment herby Piastów Śląskich i połuorła czerwonego - fragment herbu matki Bolka I, księżnej askańskiej Jadwigi), który używał jako swego herbu książę Bolko I, widnieje w mauzoleum w Krzeszowie; widoczny także na pieczęci książęcej pieszej datowanej na 1298 rok.

58 A. Kłodziński, Bolesław (Bolko) I [w:] Polski słownik biograficzny, t. 1, Kraków 1989 (reprint), s. 265-267.

59 Pole szachowe pole widoczne jest na pieczęci księżnej świdnicko-jaworskiej Agnieszki (zm. 1392), która była żoną Bolka II Małego (zm. 1368) oraz na nagrobku jej męża w mauzoleum w Krzeszowe.

60 P. Łabędzki, Herb gminy, http://www.udanin.pl/asp/pl_start.asp?ty$\mathrm{p}=14 \&$ sub $=3 \&$ menu=38\&strona $=1$ [ 12 XII 2015] . 
do walk w okresie powstania styczniowego toczacych się na terenie gminy, krzyż unicki; to nawiązanie do wiary i przeszłości, kiedy to na terenie naszej gminy istniały parafie unickie, których wyznawcy, w czasie zaboru rosyjskiego, byli dotkliwie męczeni. Krzyż ten jest też symbolem jedności i współistnienia obok siebie dwóch religii: katolickiej i unickiej ${ }^{61}$.

$\mathrm{W}$ wielu herbach widnieją trzy kłosy. To symbol zarówno upraw rolnych, zajmowania się rolnictwem, jak i dobrobytu, wystarczającej ilości pożywienia i bogactwa. Potrójne kłosy występują w wielu herbach, m. in. Żyrakowa (pow. dębicki), gdzie w polu błękitnym godło herbu Leliwa ${ }^{62}$, poniżej którego trzy kłosy złote. Trzy złote kłosy zboża widnieją w herbie powiatu głubczyckiego. W tarczy dzielonej w słup w polu prawym błękitnym kłos jęczmienia pośrodku dwóch kłosów pszenicznych, w polu lewym czerwonym lew srebrny z podwójnym ogonem i koroną złotą na głowie oraz gwiazda złota. Kłosy zboża przypominają o rolniczym charakterze powiatu. Należy zwrócić uwagę, że we wszystkich pozostałych herbach widnieją kłosy jednorodne, najczęściej identyfikowane jako kłosy pszeniczne. Srebrny lew widoczny w lewej części herbu nawiązuje do jednego z elementów herbu

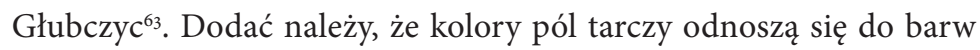
Górnego Śląska oraz województwa opolskiego, a w przeszłości były także barwami górnośląskich Piastów.

Trzy kłosy w tarczy czwórdzielnej (podzielonej w krzyż) widniały $\mathrm{w}$ herbie powiatu brodnickiego. I w tym przypadku symbolizowały rolniczy charakter terenu, codzienne zajęcia mieszkańców powiatu oraz

61 Gmina Olszanka, http://www.olszanka.gminarp.pl/historia.html [22 XII 2015].

62 W polu błękitnym półksiężyc złoty, nad którym takaż gwiazda.

$63 \mathrm{~W}$ polu czerwono-złotym tarczy dzielonej w pas postać anioła srebrnego z rozpostartymi skrzydłami podtrzymującego dwie tarcze: po prawej tarcza czerwona, na której wspięty lew srebrny zwrócony w lewo z podwójnym ogonem i złotą koroną na głowie, ponad którym gwiazda złota, po lewej tarcza błękitna z trzema bosakami w rozstrój. Powyższy herb zatwierdziła Rada Miasta uchwałą z 23 XI 1995 r. 
są symbolem dobrobytu i dostatku pożywienia. Na tarczy czwórdzielnej w polu pierwszym czerwonym odcięta dłoń, w polu drugim zielonym karp srebrny w słup pomiędzy dwoma kulami złotymi, w trzecim błękitnym trzy kłosy złote w wachlarz, w czwartym srebrnym dwie falujące wstęgi w pas (Ryc. 13). Godła zamieszczone w poszczególnych polach to herby miast leżących w powiecie brodnickim (kolejno: Brodnicy ${ }^{64}$, Górzna $^{65}$ i Jabłonowa ${ }^{66}$ ) i barwy ziemi chełmińskiej ${ }^{67}$. W 2014 roku powyższy herb zastąpiło wyobrażenie jelenia w skoku czerwonego w polu srebrnym ${ }^{68}$.

Zbliżonymi nieco do powyższego są herby powiatu przasnyskiego i gminy Olszewo-Borki (pow. ostrołęcki). Herb powiatu przasnyskiego przedstawia na tarczy czwórdzielnej w pierwszym polu srebrnym mur czerwony z trzema wieżami, w polu drugim niebieskim i trzecim zielonym trzy kłosy złote, w polu czwartym srebrnym herb Chorzel ${ }^{69}$. Należy wyjaśnić, że w polu pierwszym widnieje herb stolicy powiatu Przasnysza, w drugim i trzecim kłosy żyta, z uprawy którego słynie ziemia przasnyska, w czwartym miasta Chorzele, które położone jest na terytorium opisywanego powiatu. Herb gminy Olszewo-Borki

64 Por. R. Chudy, Herb Brodnicy, „Poznaj Swój Kraj”, nr 4:1988, s.17.

65 Załącznik nr 2 do Statutu Miasta i Gminy Górzno (Uchwała $\mathrm{nr}$ XL/222/2014) Rady Gminy w Górznie z 28 IV 2014 r.

$66 \mathrm{~W}$ herbie Jabłonowa tarcza jest koloru czerwonego.

67 Uchwała (nr XVIII/96/200o) Rady Powiatu w Brodnicy z dnia 26 października 2000 r. w sprawie ustanowienia herbu, flagi i pieczęci Powiatu Brodnickiego.

68 Uchwała (nr XLVIII/213/2014) Rady Powiatu w Brodnicy z dnia 22 kwietnia 2014 r. w sprawie ustanowienia herbu, flagi, sztandaru i pieczęci Powiatu Brodnickiego, łańcucha Starosty Brodnickiego oraz laski Przewodniczącego Rady Powiatu.

69 W srebrnym polu drzewo zielone o trzech korzeniach i dwóch konarach, z których prawy dodatkowo rozgałęziony na dwa mniejsze, na którego szczycie znajduje się owoc karczocha zielony; na lewo od pnia czarny róg myśliwski z okuciami, ustnikiem i wylotem w kolorze złotym, ułożony na opak w skos. K. Wójcikowski, R. Fidura, Uzasadnienie heraldyczno-historyczne symboli miasta i gminy Chorzele, Chorzele 2012. 
przedstawia na tarczy dzielonej w krzyż w polu pierwszym czerwonym godło herbu Trzaska, w polu drugim srebrnym trzy związane kłosy złote, w polu trzecim złotym trzy jodły zielone, w polu czwartym złotym godło herbu Nowina. Herby nawiązują do rodzin Olszewskich (Trzaska) i Brzosko (Nowina), kłosy i jodły do rolniczego i leśnego charakteru ziem gminy ${ }^{70}$.

Dodać należy, że oprócz powyższych, trzy kłosy widnieją w herbie gminy Białogard. W polu błękitnym tarczy dąb złoty pomiędzy dwoma skrzyżowanymi rybami srebrnymi o złotych płetwach z prawej i trzema kłosami złotymi i blaszkami liściowymi srebrnymi z lewej, nad którym gryf czerwony (Ryc. 14) ${ }^{71}$. Gryf nawiązuje do herbu Białogardu, który przedstawia w polu srebrnym gryf czerwony nad błękitnymi falami ${ }^{22}$. Dąb przypomina o lasach, które porastają teren gminy, natomiast ryby i kłosy do zajęć miejscowej ludności: rybołówstwa i uprawy roli.

Złote kłosy widnieją w herbach powiatu pułtuskiego i powiatu opatowskiego. Herb powiatu pułtuskiego przedstawia w polu czerwonym tarczy orzeł srebrny o dziobie i szponach srebrnych, pod którym trzy kłosy złote pomiędzy pastorałem srebrnym a takimż krzyżem $\mathrm{w}$ skos $^{73}$. Orzeł nawiązuje do herbu województwa mazowieckiego ${ }^{74}$, pastorał i krzyż są elementami herbu Pułtuska, a kłosy nawiązują do rolniczego charakteru powiatu.

70 Por. Herb gminy Olszewo-Borki czeka na akceptacje, http://epowiatostrolecki.pl/2013/10/o9/nasze-sprawy/herb-gminy-olszewo-borki-czeka-na-akceptacje,27337/ [20 XI 2015].

71 Uchwała Urzędu Gmin w Białogardzie (nr L/247/o2") z 9 x 2002 r.

72 Uchwała Urzędu Miasta w Białogardzie (nr xvi/146/o4) z 3 III $2004 \mathrm{r}$.

73 Uchwała Rady Powiatu w Pułtusku (Nr xxxiv/228/2002) z 27 II $2002 \mathrm{r}$.

$74 \mathrm{~W}$ polu czerwonym orzeł biały o dziobie i szponach złotych. Uchwała $\mathrm{Nr}$ 9o/o6 Sejmiku Województwa Mazowieckiego z dnia 29 maja 2006 r. w sprawie wzoru herbu Województwa Mazowieckiego oraz zasad jego używania. (Dz. Urz. woj. mazowieckiego z 2006 r. Nr 139, poz. 4595). 
Z kolei herb powiatu opatowskiego przedstawia w tarczy dwudzielnej $\mathrm{w}$ pas $\mathrm{w}$ polu górnym dwudzielnym $\mathrm{w}$ słup $\mathrm{w}$ polu pierwszym błękitnym basztę srebrną z dwoma wykuszami i otworem bramnym o czarnym prześwicie, nakrytą trzema stożkowymi dachami czerwonymi zwieńczonymi srebrnymi gałkami, w polu drugim czerwonym srebrny topór ${ }^{75}$, w podstawie tarczy sześć pasów poziomych naprzemiennie białych i czerwonych, na nich trzy kłosy złote. Srebrna wieża nawiązuje do herbu Opatowa ${ }^{76}$, herb Topór o wzniesionym przez Ossolińskich zamku o zamku w Ujeździe, który to zamek położony jest na terenie powiatu opatowskiego ${ }^{77}$, biało-czerwone pasy w polu dolnym odnoszą się do barw Ziemi Sandomierskiej, a kłosy zboża do rolniczego charakteru powiatu opatowskiego i zajęć większości jego mieszkańców.

Orzeł oraz kłosy występują także w herbie powiatu żuromińskiego. W tarczy dwudzielnej w słup, w polu lewym czerwonym półorzeł biały, w polu prawym błękitnym gwiazda i księżyc rogami w dół złote, nad którym trzy takież kłosy w wachlarz zaćwieczone w barku księżyca ${ }^{78}$. I w tym przypadku kłosy nawiązują do rolniczego charakteru powiatu.

Trzy kłosy, jako elementy godeł, pojawiają się także w herbach innych gmin, m.in. w herbie gminy Dobrcz (pow. bydgoski), w którym na tarczy dzielonej w skos z lewej w polu pierwszym zielonym trzy kłosy pszeniczne złote, w polu drugim szarym ${ }^{79}$ skrzyżowane dwie strzały i miecz, nad którymi trzy serca płomieniste czerwone. Interesująca

75 Niekiedy w opisach herbu opatowskiego nazywanym „Krzyżtopór” Herb powiatu opatowskiego, http://swietokrzyskie.regiopedia.pl/wiki/herb-powiatu-opatowskiego [21 XII 2015].

76 M. Gumowski, Herby..., s. 257.

77 Więcej na temat zamku Krzyżtopór: J. Myjak, Opatów i okolice. Zamek Krzyżtopór w Ujeździe (przewodnik), Sandomierz 2008.

78 Herb i flaga, http://www.zuromin-powiat.pl/powiat/herb-i-flaga [1 XII 2015].

79 W opisie heraldycznym na stronach Urzędu Gminy określone jako srebrne. Herb Gminy Dobrcz, http://www.dobrcz.bip.net.pl/?a=2208 [11 XII 2015]. 
jest nie tylko kompozycja herbu, ale i interpretacja poszczególnych elementów herbu, która znajduje się na oficjalnych stronach Urzędu Gminy: Znaczenie symboli: kłos - praca w pocie czoła, obowiazek pracy na ziemi, symbol obfitości i dostatku; miecz - symbol mocy ducha i miłości, symbol zręczności; serca z płomieniami - symbol Trzech Cnót Boskich: wiary, nadziei i miłości; liczba 3 - symbol doskonałości wszystkich spraw duchowych; barwa biała - przedstawia życie i jego źródło, jest wyrazem prawdy i jedności oraz zwycięstwa dobra nad złem, jest symbolem czystości, niewinności moralnej i pokoju; barwa zielona - symbol życia; barwa żótta - barwa umiłowania ziemi i dóbr stworzonych; barwa srebrna - symbol czystości, niewinności ${ }^{80}$.

Trzy kłosy odnajdujemy także w herbie miejscowości i gminy Słubice (pow. płocki), w którym na tarczy dzielonej z lewa w skos białą wstęgą w polu pierwszym czerwonym godło herbu Ostoja ${ }^{{ }_{11}}$, w drugim błękitnym trzy kłosy złote w wachlarz. Herb Ostoja nawiązuje do Józefa Andrzeja Mikorskiego(zm. po 1818) - kasztelana rawskiego, starosty gostyńskiego i dziedzica Słubic ${ }^{82}$, kłosy - do rolniczego charakteru terenu gminy, a biała wstęga do rzeki Tamy przepływającej przez gminę i wpadającej do Wisły.

Trzy kłosy, obok powyższych, widnieją w herbie gminy Łaskarzew (pow. garwoliński) ${ }^{83}$. W błękitnym polu skrzyżowany klucz złoty i miecz srebrny o złotej rękojeści, nad którymi trzy kłosy złote w wachlarz. Skrzyżowany klucz i miecz nawiązują do herbu Łaskarzewa ${ }^{84}$,

8 o Herb Gminy Dobrcz, http://www.dobrcz.bip.net.pl/?a=2208 [11 XII 2015].

81 W polu czerwonym między dwoma półksiężycami złotymi barkami ku sobie w pas, miecz o głowni srebrnej i jelcu złotym. Por. J. Szymański, Herbarz rycerstwa polskiego z XVI wieku, Warszawa 2001, s. 209.

82 Por. S. Uruski, Rodzina. Herbarz szlachty polskiej, Warszawa 1914, t. 11, S. 56 .

83 Miejscowość otrzymała prawa miejskie w 1418 r. z nadania króla Władysława Jagiełły na prośbę bpa poznańskiego Andrzeja Łaskarza, utraciło je w 1870 r. w ramach carskich restrykcji. Na nowo pełne prawa miejskie przywrócono miejscowości w $1969 \mathrm{r}$.

84 Por. A. Plewako, J. Wanag, Herbarz..., s. 114. 
w którym widnieją dwa skrzyżowane klucze i miecz ${ }^{85}$. Miecz odnosi się do władzy królewskiej, która rozciągała się w przeszłości nad częścią miejscowości, które wchodzą w skład gminy. To także symbol bohaterstwa mieszkańców. Kłosy natomiast nawiązują do rolniczego charakteru miejscowości.

Z kolei herb gminy Chąśno (pow. łowicki) przedstawia w polu błękitnym dwie lilie srebrne w pas, pod którymi trzy kłosy złote w wachlarz ${ }^{86}$. Trzy związane kłosy powyżej rogu myśliwskiego widnieją w herbie gminy Połajewo (pow. czarnkowsko-trzcianecki) oraz w herbie gminy Dygowo (powiat kołobrzeski). W drugim $\mathrm{z}$ wymienionych $\mathrm{w}$ tarczy dwudzielnej w pas w polu górnym złotym dwie gałązki dębowe zielone, w polu dolnym dwudzielnym w słup w polu pierwszym zielonym trzy kłosy złote z takąż przepaską, w polu drugim błękitnym ryba srebrna pod którą dwie wstęgi srebrne ${ }^{87}$.

W jednym tylko przypadku w polskiej heraldyce świeckiej występują cztery kłosy. Widoczne są w herbie gminy Gierałtowice (pow. gliwicki). Herb przedstawia w polu tarczy błękitnej zamek oflankowany zamek srebrny z wieżą bramną z czterema czarnymi oknami, poniżej cztery kłosy złote (Ryc. 15). Zamek nawiązuje do zabytkowych budowli, które znajdują się na terenie gminy: zamki w Chudowie i Przyszowicach oraz dwór w Gierałtowicach, natomiast kłosy symbolizują rolniczy charakter miejscowości, które leżą w granicach gminy. Warto dodać, że kilka miejscowości położonych na terenie gminy posiadało w herbach elementy agrarne. Były to: Chudowa (sierp), Paniówek (kosa i grabie), Gierałtowic (snop) ${ }^{88}$.

85 Ponieważ Łaskarzew wchodził w skład dóbr kapituły poznańskiej, w herbie której widniały atrybuty jej patronów św. Piotra Apostoła (klucze) i św. Pawła Apostoła (miecz), dlatego w herbie tejże miejscowości pojawiły się klucze i miecz.

86 Uchwała Rady Gminy Chąśno (Nr xxıv/111/2009).

87 Uchwała Rady Gminy w Dygowie (nr xIx/16o/o1) z 20 II 2001 r. w sprawie herbu gminy Dygowo.

88 Herb Gminy Gierałtowice, http://gieraltowice.pl/152/herb-gminygieraltowice.html [5 XII 2015]. 
Od wyżej przedstawionych odbiega kompozycyjnie herb gminy Wielkie Oczy, w którym widnieje wieniec z kłosów. Herb przedstawia w polu błękitnym tarczy ukleję srebrną w prawo, poniżej której wieniec z 10 kłosów złotych (Ryc. 16). Według lokalnej tradycji ukleja - zwana także wielkookiem - odnosi się do nazwy miejscowości oraz do dwóch stawów rybnych, które mają przypominać dwoje oczu. Kłosy nawiązują do rolniczych tradycji regionu ${ }^{89}$.

Symbolika florystyczna w kulturze europejskiej posiada bogatą paletę możliwości interpretacyjnych. Omawiane kosy występują zarówno w semantyce sacrum jak i profanum. W heraldyce posiada szczególny wymiar odnosząc się do szczególnego krajobrazu historyczno - kulturowego. Wyraźnie widać to zwłaszcza w wypadku heraldyki miejskiej i gminnej.

\section{Bibliografia}

\section{ŹRóDŁA}

Uchwała (nrr XVIII/96/200o) Rady Powiatu w Brodnicy z dnia 26 października 2000 r. w sprawie ustanowienia herbu, flagi i pieczęci Powiatu Brodnickiego.

Uchwała Rady Gminy Chąśno (Nr xxIv/111/2009).

Uchwała Rady Gminy w Dygowie (nr XIx/16o/o1) z 20 II 2001 r. w sprawie herbu gminy Dygowo.

Uchwała Rady Gminy Zławieś Wielka Nr xx/231/2002 z 26 IV 2002 r.

Uchwała Rady Powiatu w Pułtusku (Nr xxxIv/228/2002) z 27 II 2002 r.

Uchwała Urzędu Gmin w Białogardzie (nr L/247/02") z 9 x 2002 r.

Uchwała Urzędu Miasta w Białogardzie (nr xvi/146/o4) z 3 III 2004 r. Załącznik nr 2 do Statutu Miasta i Gminy Górzno (Uchwała nr xL/222/2014) Rady Gminy w Górznie z 28 IV 2014 r.

89 K. Bołotiuch, Herb, http://wielkieoczy.info.pl/asp/pl_start.asp?typ= $14 \&$ menu $=6 \&$ strona $=1$ [5 XII 2015]. 


\section{OPRACOWANIA}

Adamczewski M., Pieczęcie urzędowe władz lokalnych z obszaru Polski centralnej, cz. 3, Łódz 2010.

Białecki T., Herby Miast Pomorza Zachodniego, Szczecin 1991.

Bieniarzówna J., Orsetti Guglielmo (zm. 1659) [w:] Polski słownik biograficzny, t. 24, Wrocław-Warszawa-Kraków-Gdańsk 1979.

Bołotiuch K., Herb, http://wielkieoczy.info.pl/asp/pl_start.asp?ty$\mathrm{p}=14$ \&menu $=6$ \&strona $=1$ [5 XII 2015].

Chudy R., Herb Brodnicy, „Poznaj Swój Kraj”, nr 4:1988, s.17.

Gajowniczek Z. T., Gmina wiejska i miejsko-wiejska w Polsce jako obszar odniesienia w edukacji regionalnej, Warszawa 2014.

Gajowniczek Z. T., Na tropach tajemnic historii Cegłowa, Cegłów 1999.

Gmina Olszanka, http://www.olszanka.gminarp.pl/historia.html [22 XII 2015].

Górski K., Arszyński M., Barciany. Dzieje zamku i ziemi do połowy XV wieku, Olsztyn 1967.

Gumowski M., Herby miast polskich, Warszawa 1960.

Gumowski M., Herby i pieczęcie miejscowości województwa ślaskiego z 438 rycinami, Katowice 1939.

Herb Dziergowic, http://dziergowice.pl/herb-dziergowic,15 [12 XI 2015]. Herb Gminy Dobrcz, http://www.dobrcz.bip.net.pl/?a=2208 [11 XII 2015]. Herb Gminy Gieraltowice, http://gieraltowice.pl/152/herb-gminy-gieraltowice.html [5 XII 2015].

Herb gminy Łodygowice, http://www.lodygowice.pl/nasza-gmina/herb. html [12 XII 2015].

Herb gminy Olszewo-Borki czeka na akceptacje, http://epowiatostrolecki. $\mathrm{pl} /$ 2013/10/o9/nasze-sprawy/herb-gminy-olszewo-borki-czeka-na-akceptacje,27337/ [20 XI 2015].

Herb gminy Stary Lubotyń, http://www.encyklopedia.biolog.pl/index. php?haslo=Herb_gminy_Stary_Luboty\%C5\%84 [27 XI 2015].

Herb i flaga gminy, http://laszki.pl/gmina/herb [21 xI 2015].

Herb i flaga, http://www.zuromin-powiat.pl/powiat/herb-i-flaga [1 XII 2015]. 
Herb Korsz, http://www.korsze.com/Historia\%2oKorsz/herb.htm [10 XII 2015].

Herb powiatu opatowskiego, http://swietokrzyskie.regiopedia.pl/wiki/ herb-powiatu-opatowskiego [21 XII 2015].

Izbicko - historia, http://portal-strzelce.pl/strony/izbicko-historia/ [27 XI 2015].

Jasiński K., Jeszcze o Zwinisławie żonie Mszczuja I, „Zapiski Towarzystwa Naukowego w Toruniu", 16:1950, s. 85.

Kalendarium Gminy Lipce Reymontowskie, http://www.lipcereymontowskie.pl/index.php? $\mathrm{p}=$ historia_kalendarium [1 XII 2015].

Kłodziński A., Bolesław (Bolko) I [w:] Polski słownik biograficzny, t. 1, Kraków 1989 (reprint), s. 265-267.

Krause E., Monografia historyczna Miasta i Gminy Janikowo - od pradziejów ludzkości do końca Xx wieku, Janikowo 2002.

Krupa T., Nasz herb, „Gazeta Łochowska” nr 103 (135):2006.

Kulikowski A., Wielki herbarz rodów polskich, Warszawa 2005.

Labuda G., Fragmenty dziejów Słowiańszczyzny Zachodniej, t. 3, Poznań 1975.

Leś-Runicka M., Historia kopalni węgla kamiennego Janina w Libiążu, Libiąż 2008.

Łabędzki P., Herb gminy, http://www.udanin.pl/asp/pl_start.asp?ty$\mathrm{p}=14$ \&sub $=3$ \&menu $=38$ \&strona $=1$ [12 XII 2015].

Marecki J., Rotter L., Jak czytać wizerunki świętych. Leksykon atrybutów i symboli hagiograficznych, Kraków 2013.

Myjak J., Opatów i okolice. Zamek Krzyżtopór w Ujeździe (przewodnik), Sandomierz 2008.

Niesiecki K., Herbarz polski, t. 4, Lipsk 1841.

Ostrowski J., Księga herbowa rodów polskich, cz. 2, Warszawa 1901.

Plewako A., Wanag J., Herbarz miast polskich, Warszawa 1994.

Przybyszewski S. M., Kazimierza Wielka, Kielce 2002.

Rurawski J., Władysław Reymont, Warszawa 1988.

Sęczyk S., Dzieje Łochowa i okolic, http://kapliczkiwpolsce.blogspot. com/2012/11/dzieje-ochowa-i-okolic-wg-stanisawa.html [12 XII 2015]. 
Sikorski J., Historia wsi Barciany, http://www.jerzysikorski.pl/historia-wsi-barciany [18 XI 2015].

Symbole gminy Kleszczów, http://www.kleszczow.com/symbole.php [10 XI 2015].

Symbolika herbu Gminy Morzeszczyn, http://nowa.morzeszczyn.pl/ herb-gminy/symbolika-herbu-gminy-morzeszczyn.html [12 XII 2015].

Szymański J., Herbarz rycerstwa polskiego z XVI wieku, Warszawa 2001.

Uruski S., Rodzina. Herbarz szlachty polskiej, t. 11, Warszawa 1914.

Wójcikowski K., Fidura R., Uzasadnienie heraldyczno-historyczne symboli miasta i gminy Chorzele, Chorzele 2012.

Znamierowski A., Dudziński P., Wielka księga heraldyki, Warszawa 2008.

Znamierowski A., Herbarz rodowy, Warszawa 2004.

Znamierowski A., Pieczęcie i herby Śląska Cieszyńskiego, Górki Wielkie-Cieszyn 2011. 



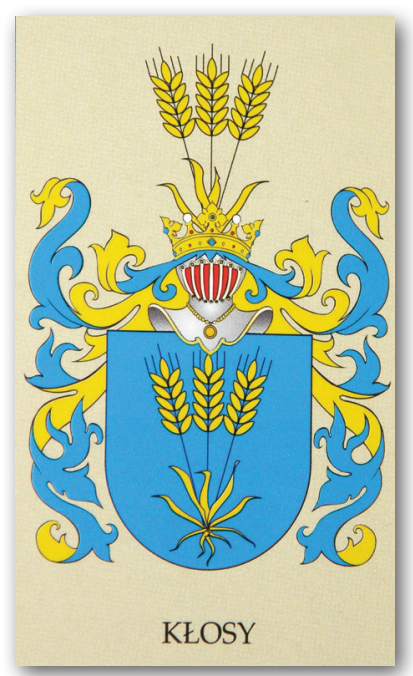

Ryc. 1. Herb Kłosy.

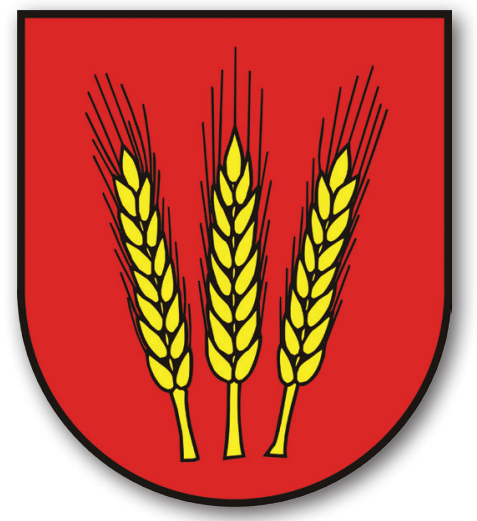

Ryc. 3. Herb miasta i gminy Jabłonowo Pomorskie.

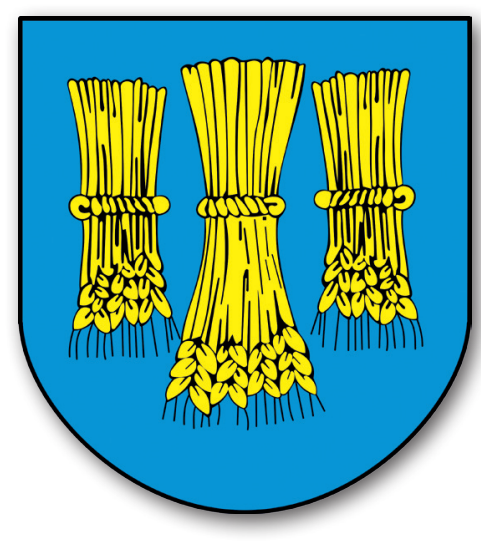

Ryc. 2. Herb Wałcza.

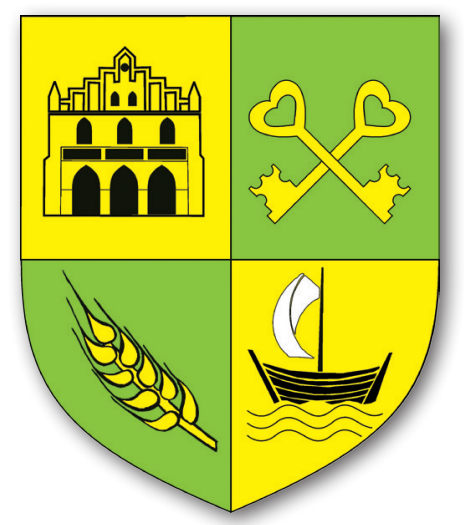

Ryc. 4. Herb gminy Łodygowice. 


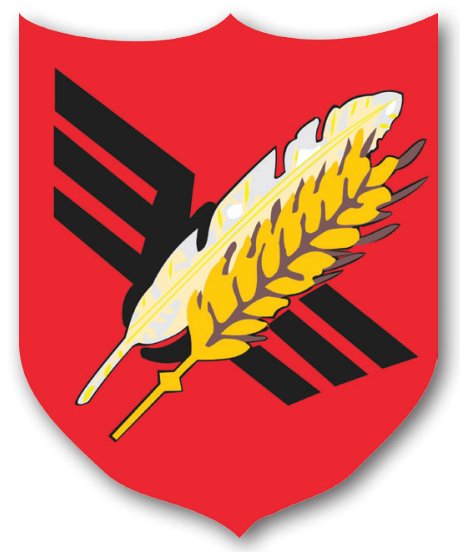

Ryc. 5. Herb miasta Koluszki.

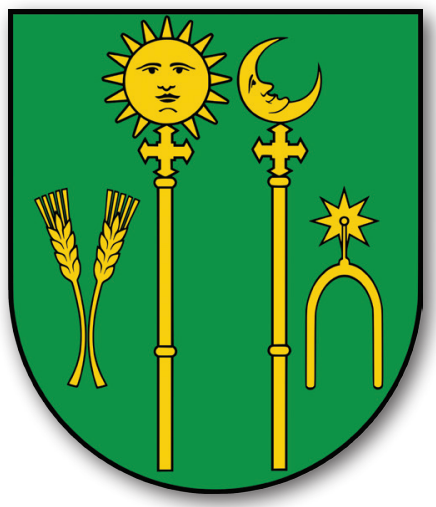

Ryc. 7. Herb gminy Stary Lubotyń.

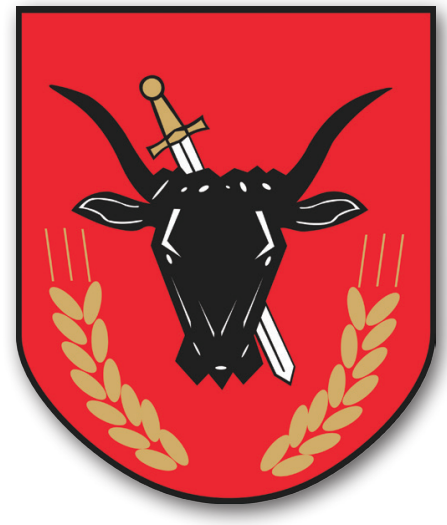

Ryc. 6. Herb Kazimierzy Wielkiej.

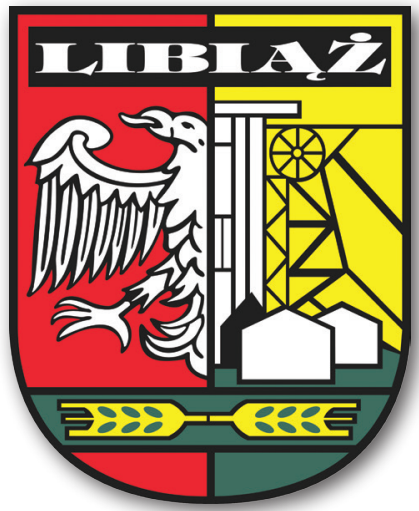

Ryc. 8. Herb Libiąża. 


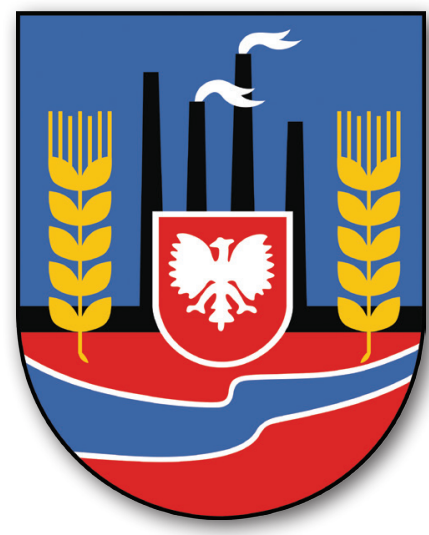

Ryc. 9. Herb Myszkowa.

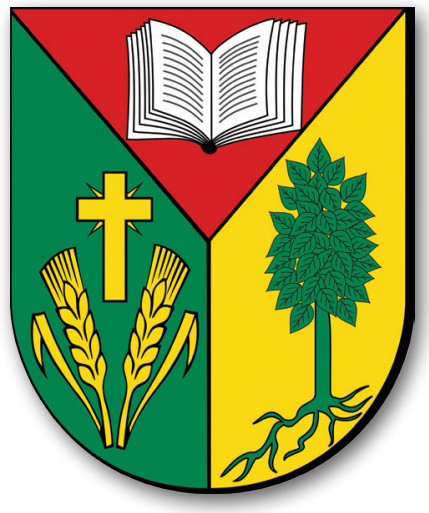

Ryc. 11. Herb miejscowości i gminy Lipce Reymontowskie.

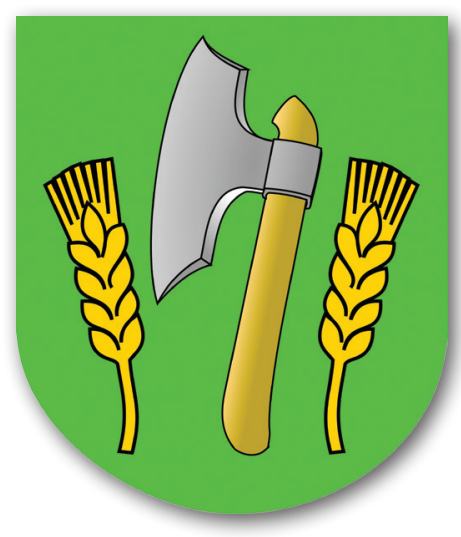

Ryc. 10. Herb gminy Barciany.

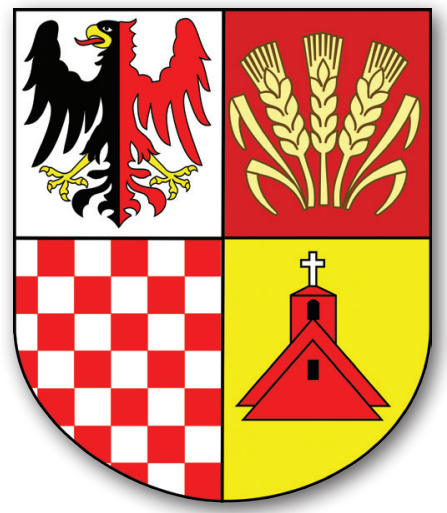

Ryc. 12. Herb gminy Udanin. 


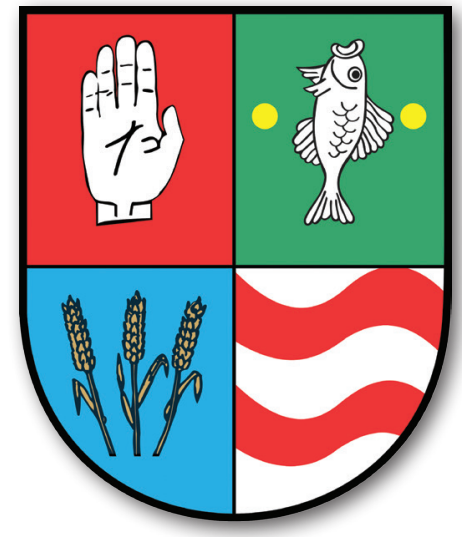

Ryc. 13. Herb powiatu brodnickiego.

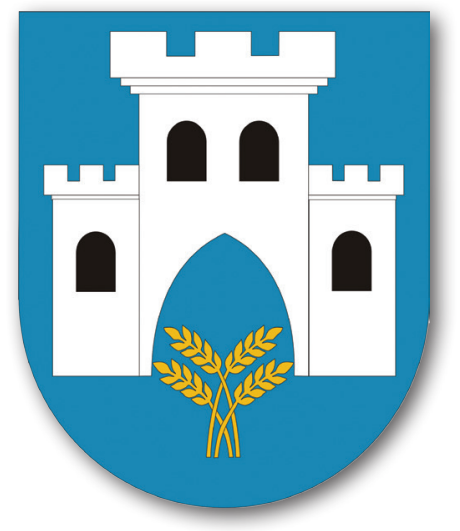

Ryc. 15. Herb gminy Gierałtowice.

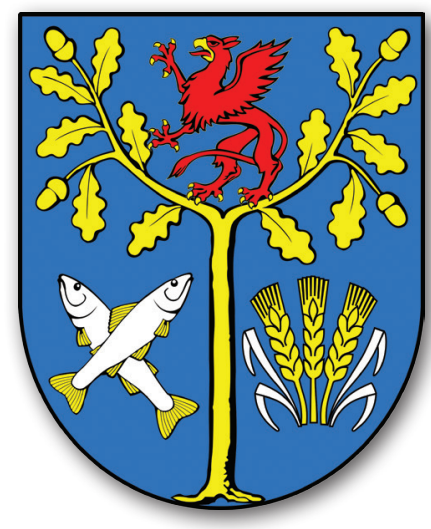

Ryc. 14. Herb gminy Białogard.

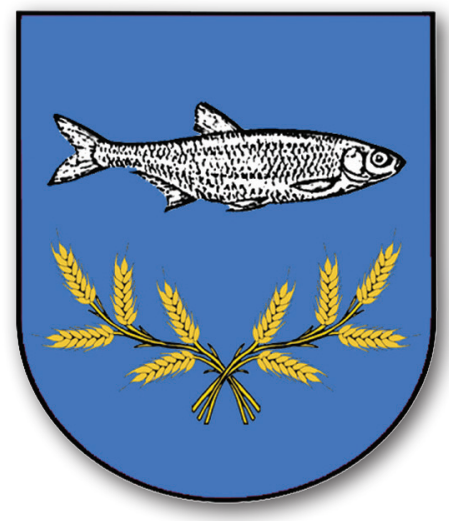

Ryc. 16. Herb gminy Wielkie Oczy. 